\title{
HUBUNGAN KUNJUNGAN KELUARGA TERHADAP KESEMBUHAN PASIEN RISIKO PERILAKU KEKERASAN DI RUMAH SAKIT JIWA TAMPAN PEKANBARU
}

\author{
Juliana Putri ${ }^{1}$, Erna Marni ${ }^{2}$, Dian Roza Adila ${ }^{3}$ \\ 1,2,3 Mahasiswa Program Studi Ilmu Keperawatan \\ STIKes HANG TUAH PEKANBARU 2018 \\ Email: liasukoco27@gmail.com
}

\begin{abstract}
Abstrak
Gangguan jiwa merupakan keadaan seseorang yang memiliki gangguan pada fungsi mental, yang meliputi emosi, fikiran, kemauan, motivasi, keinginan, perasaan, dan persepsi sehingga mengganggu individu tersebut dalam proses kehidupan dilingkungan masyarakat. Keluarga merupakan bagian terpenting dalam kesembuhan pasien jiwa, sehingga pasien jiwa merasa diperhatikan oleh keluarganya. Penelitian ini bertujuan untuk mengetahui hubungan kunjungan keluarga terhadap kesembuhan pasien risiko perilaku kekerasan, dengan menggunakan metode kuantitatif dengan pendekatan cross sectional dengan jumlah responden 30 orang. Teknik yang digunakan yaitu total sampling. Analisa yang digunakan adalah analisa bivariat dengan menggunakan uji chi square. Instrumen penelitian ini menggunakan koesioner. Dari hasil uji chi square dapat disimpulkan bahwa terdapat hubungan yang signifikan antara kunjungan keluarga terhadap kesembuhan pasien risiko perilaku kekerasan dengan p value 0,002 <0,05. Kepada pihak Rumah Sakit Jiwa Tampan Pekanbaru untuk menetapkan ideal kunjungan keluarga dan membuat buku kunjungan keluarga pada setiap ruangan rawat inap dan juga memaksimalkan fungsi dari buku kunjungan di Rumah Sakit Jiwa Tampan, serta memotivasi keluarga supaya keluarga ingin mengunjungi anggota keluarganya yang berada di Rumah Sakit Jiwa.
\end{abstract}

Kata kunci: Gangguan Jiwa, Kunjungan Keluarga, Resiko Perilaku Kekerasan, Kesembuhan Pasien Risiko Perilaku Kekerasan

\begin{abstract}
Abstrak
Mental disorder is a state of someone who has a mental function disorder, which includes emotions, thoughts, will, motivation, desires, feelings, and perceptions so as to disturb the individual in the process of life in the community. Family is the most important part in healing mental patients, so that mental patients feel cared for by their families. This study aims to determine the relationship of family visits to the recovery of risk for violent behavior patient, using a quantitative method with a cross sectional approach with 30 respondents. The technique used was total sampling. The analysis used was bivariate analysis using chi square test. This research instrument used questionnaire. From the results of the chi square test it can be concluded that there was a significant relationship between family visits to the recovery of risk for violent behavior patient with $p$ value $0.002<0.05$. To the Rumah Sakit Jiwa Tampan Pekanbaru to set the ideal family visits and make a book of family visits in each inpatient room and maximize the function of the family visits book in Rumah Sakit Jiwa Tampan, and motivates the family so that the family wants to visit family members who are in the Mental Hospital.
\end{abstract}

Keywords: mental disorder, family visits, risk of violent behavior, healing is at risk of violent behavior

\section{PENDAHULUAN}

Gangguan jiwa merupakan suatu keadaan seseorang yang memiliki gangguan pada fungsi mental, yang meliputi: emosi, fikiran, kemauan, motivasi, keinginan, perasaan, dan persepsi 
Juliana Putri ${ }^{1}$, Erna Marni ${ }^{2}$, Dian Roza Adila ${ }^{3}$,Hubungan Kunjungan Keluarga terhadap Kesembuhan Pasien Risiko Perilaku Kekerasan di Rumah Sakit Jiwa Tampan Pekanbaru

sehingga mengganggu individu tersebut dalam proses kehidupan dilingkungan masyarakat (Nasir \& Muhith, 2011).

Data dari Kementrian kesehatan (Kemenkes) (2016), terdapat sekitar 35 juta orang yang terkena depresi, 60 juta orang terkena gangguan bipolar, 21 juta orang terkena skizofrenia, serta 47,5 juta terkena demensia. Di Indonesia jumlah kasus gangguan jiwa terus bertambah. Menurut Riskesdas (2013) prevalensi gangguan jiwa berat, seperti skizofrenia mencapai 400.000 orang dan pada gangguan mental emosional yang ditandai dengan gejala depresi dan kecemasan mencapai sekitar 14 juta orang dari jumlah penduduk Indonesia.

Risiko perilaku kekerasan adalah suatu bentuk perilaku agresi (aggressive behavior) yang akan menyebabkan penderita berisiko menyakiti diri sendiri dan menyakiti orang lain termasuk hewan dan benda-benda. Hal tersebut terjadi dikarenakan adanya ancaman yang membuat emosi seseorang meningkat hal itu didapat baik dari orang lain maupun keluarga (Muhith, A, 2015).

Data risiko perilaku kekerasan yang tergolong dalam skizofrenia paranoid yang diperoleh dari rumah sakit jiwa Tampan pada tahun 2015 yaitu sebanyak 497 orang, dan pada tahun 2017 mengalami peningkatan yaitu 690 orang. Dari 690 terdapat 555 orang berjenis kelamin lakilaki dan 135 orang berjenis kelamin perempuan. Data tersebut tergolong tinggi karena dilihat pada tahun 2015 dan angka kejadian pada diagnosa lain lebih rendah dari diagnos risiko perilaku kekerasan. Sehingga pada diagnosa risiko perilaku kekerasan ini memerlukan penanganan yang optimal sehingga dapat meminimalkan terjadinya perilaku kekerasan (Rekam Medis RSJ Tampan, 2017).

Penanganan pada pasien risiko perilaku kekerasan dapat dilakukan dengan memberikan obat-obatan yang telah di indikasikan oleh dokter (Dion \& Betan, 2013). Penatalaksanaan yang lain yaitu memberikan terapi keluarga seperti dukungan keluarga yaitu dalam bentuk kunjungan keluarga, saling asuh, menerima anggota keluarga, mendukung antar anggota keluarga, memberi perhatian satu sama lain, memberi cinta kasih dan kehangatan (Dion \& Betan, 2013).

Keluarga merupakan suatu pendukung utama yang memberi perawatan pada saat anggota keluarga mengalami sehat atau sakit (Yosep \& Titin, 2014). Maka dibuatlah terapi keluarga agar keluarga dapat mengembangkan dan meningkatkan kemampuan keluarga dalam mengatasi masalah kesehatan keluarga (Yosep \& Titin, 2014).

Berdasarkan survei pendahuluan yang dilakukan peneliti di Rumah Sakit Jiwa Tampan Pekanbaru pada 6 orang perawat 
ruangan, diperoleh informasi bahwa kunjungan keluarga itu sangat penting karena dapat mempengaruhi kesembuhan dari pasien jiwa. Selain kunjungan keluarga kesembuhan pasien jiwa juga dipengaruhi oleh obat-obatan dan peran perawat itu sendiri.

Selain itu dari 6 orang perawat ruangan tersebut secara keseluruhan menyatakan bahwa keluarga pasien tidak mengakui anggota keluarganya yang mengalami gangguan jiwa dan sebagian besar tidak ada keluarga yang berkunjung kerumah sakit jiwa. Berdasarkan latar belakang diatas, peneliti tertarik untuk melakukan penelitian yang berjudul hubungan kunjungan keluarga terhadap kesembuhan pasien risiko perilaku kekerasan di Rumah Sakit Jiwa Tampan Pekanbaru.

\section{METODE}

Jenis dan desain penelitian ini yaitu kuantitatif dengan pendekatan deskriptif korelasi dan menggunakan pendekatan cross sectional. Responden dalam penelitian ini berjumlah 30 resoponden dengan menggunakan tekning total sampling. Lokasi penelitian ini dilakukan di Rumah Sakit Jiwa Tampan Pekanbaru pada ruang rawat inap yang dilakukan selama 3 hari yaitu pada tanggal 27 sampai dengan 29 Agustus 2018 dengan memberikan kuesioner. Analisis yang dilakukan dalam penelitian ini, analisis univariat dan bivariat. Uji statistik yang digunakan uji chi square, uji statistik ini dilakukan untuk mengetahui hubungan kunjungan keluarga terhadap kesembuhan pasien risiko perilaku kekerasan.

\section{HASIL}

Berdasarkan penelitian yang telah dilakukan di ruangan rawat inap Rumah Sakit Jiwa Tampan Provinsi Riau tentang hubungan kunjungan keluarga terhadap pasien risiko perilaku kekerasan diperoleh hasil sebagai berikut:

\section{A. Analisis Univariat}

Tabel 1.

Distribusi karakteristik responden berdasarkan umur pasien risiko perilaku kekerasan di Rumah Sakit Jiwa Tampan Pekanbaru

\begin{tabular}{lllll}
\hline Karakteristik & Rerata & SD & Min & Max \\
\hline Usia & 30,80 & 5,054 & 20 & 40 \\
\hline
\end{tabular}

Berdasarkan tabel 1 diketahui bahwa rerata usia responden pada penelitian ini adalah 30.80 tahun.

Tabel 2.

Distribusi karakteristik jenis kelamin pasien risiko perilaku kekerasan di rumah sakit jiwa tampan pekanbaru

\begin{tabular}{lll}
\hline Jenis Kelamin & $\begin{array}{l}\text { Frekuensi } \\
\text { (f) }\end{array}$ & Persentase(\%) \\
\hline Laki-Laki & 22 & 73,3 \\
\hline Perempuan & 8 & 26,7 \\
\hline Total & 30 & 100 \\
\hline
\end{tabular}

Berdasarkan tabel 2 diketahui bahwa mayoritas pasien risiko perilaku kekerasan di Rumah Sakit Jiwa Tampan Pekanbaru 
Juliana Putri ${ }^{1}$, Erna Marni ${ }^{2}$, Dian Roza Adila ${ }^{3}$,Hubungan Kunjungan Keluarga terhadap Kesembuhan Pasien Risiko Perilaku Kekerasan di Rumah Sakit Jiwa Tampan Pekanbaru

berjenis kelamin laki-laki yaitu sebanyak 22 orang $(73,3 \%)$.

Tabel 3 .

Distribusi frekuensi tingkat kunjungan keluarga

\begin{tabular}{llll}
\hline No & $\begin{array}{l}\text { Tingkat } \\
\text { Kunjungan }\end{array}$ & $\begin{array}{l}\text { Frekuensi } \\
(\mathrm{f})\end{array}$ & $\begin{array}{l}\text { Persentase } \\
(\%)\end{array}$ \\
\hline 1. & Baik & 2 & 6,7 \\
\hline 2. & Buruk & 28 & 93,3 \\
\hline & Total & 30 & 100 \\
\hline
\end{tabular}

Berdasarkan tabel 3 dapat dilihat bahwa frekuensi tingkat kunjungan keluarga mayoritas dengan kategori buruk atau tidak pernah berkunjung dengan jumlah 28 orang $(93,3 \%)$.

Tabel 4.

Distribusi frekuensi kesembuhan pasien risiko perilaku kekerasan

\begin{tabular}{llll}
\hline No & $\begin{array}{l}\text { Tingkat } \\
\text { Kesembuhan }\end{array}$ & $\begin{array}{l}\text { Frekuensi } \\
(\mathrm{f})\end{array}$ & $\begin{array}{l}\text { Persentase } \\
(\%)\end{array}$ \\
\hline 1 & Baik & 2 & 6,7 \\
\hline 2 & Kurang baik & 28 & 93,3 \\
\hline & Total & 30 & 100 \\
\hline
\end{tabular}

Berdasarkan tabel 4 dapat terlihat bahwa mayoritas responden memiliki kesembuhan kurang baik berjumlah 28 orang ( $93,3 \%)$.

\section{B. Analisis Bivariat}

Tabel 5.

Hubungan kunjungan keluarga terhadap kesembuhan pasien risiko perilaku kekerasan

\begin{tabular}{|c|c|c|c|c|c|c|c|}
\hline $\begin{array}{l}\text { Kunjungan } \\
\text { Keluarga }\end{array}$ & \multicolumn{4}{|c|}{ Kesembuhan } & \multicolumn{2}{|c|}{ Total } & $\begin{array}{l}P \\
\text { value }\end{array}$ \\
\hline & & g baik & & & & & \\
\hline & $\mathrm{n}$ & $\%$ & $\mathrm{n}$ & $\%$ & $\mathrm{n}$ & $\%$ & \\
\hline Buruk & 28 & 93,3 & 0 & 0 & 28 & 93,3 & 0,002 \\
\hline Baik & 0 & 0 & 2 & 6,7 & 2 & 6,7 & \\
\hline Jumlah & 28 & 93,3 & 2 & 6,7 & 30 & 100 & \\
\hline
\end{tabular}

Berdasarkan tabel 5 didapatkan bahwa dari $28(93,3 \%)$ orang yang tidak dikunjungi (buruk) memiliki tingkat kesembuhan kurang baik, sedangkan tidak ada responden yang memiliki tingkat kesembuhan baik. Untuk satu kali kunjungan (baik) dengan kesembuhan kurang baik $0(0 \%)$ sedangkan untuk satu kali kunjungan (baik) dengan kesembuhan baik terdapat $2(6,7 \%)$. Hasil uji statistik dengan menggunakan uji Chi Square diperoleh $\mathrm{p}$ value 0,002 yaitu $\mathrm{p}$ value $<\alpha$ $(0,05)$ sehingga Ho ditolak, artinya ada hubungan signifikan antara kunjungan keluarga terhadap kesembuhan pasien risiko perilaku kekerasan.

\section{PEMBAHASAN}

\section{Karakteristik Responden}

Umur

Berdasarkan dari hasil penelitian yang telah dilakukan menunjukkan usia rerata responden adalah 30,80 tahun, Potter dan Perry (2010) mengatakan bahwa usia tersebut termasuk dalam kategori dewasa muda yaitu dalam rentang 20-40 tahun. Dalam rentang usia tersebut individu mulai menjadi individu yang mandiri dan mempunyai tanggung jawab.

Usia mempengaruhi seseorang dalam melakukan tindakan, ketika seseorang telah memasuki usia dewasa muda maka individu akan mengalami penurunan ketergantungan pada orang tua, 
dikarenakan mereka harus tinggal terpisah dari orang tua demi melanjutkan masa depan mereka seperti bersekolah, bekerja atau pun berumah tangga (Kirana, Nauli, Novayelinda, 2014). Saat koping individu tidak efektif dalam menghadapi suatu kegagalan dalam proses berkembang maka individu tersebut akan mengalami perubahan psikis. Ketika individu tidak mampu mengatasi perubahan psikis tersebut maka individu tersebut akan berisiko terkena gangguan jiwa (Kirana, Nauli, Novayelinda, 2014).

\section{Jenis Kelamin}

Berdasarkan dari hasil penelitian yang telah dilakukan menunjukkan jenis kelamin pada responden terbanyak yaitu berjenis kelamin laki-laki yang berjumlah 22 orang $(73,3 \%)$. Hasil penelitian ini sejaan dengan teori Keliat (2011) yang mengatakan bahwa laki-laki berisiko tinggi melakukan perilaku kekerasan dibandingkan perempuan dikarenakan lakilaki cenderung tidak mampu mengontrol emosinya sedangkan laki-laki tergesa-gesa dalam mengambil keputusan. Sedangkan perempuan memiliki fungsi sosial dan pengambilan keputusan dalam pengendalian emosi lebih baik dari pada laki-laki.

\section{Kunjungan Keluarga}

Berdasarkan hasil analisis univariat dari 30 responden diketahui bahwa, sebagian besar responden memiliki kunjungan keluarga yang buruk yaitu 28 orang $(93,3 \%)$ sedangkan yang memiliki kunjungan keluarga baik 2 orang $(6,7 \%)$. Hasil tersebut dapat mempengaruhi kesembuhan pasien risiko perilaku kekerasan karena kunjungan keluarga sangat diharapkan pasien dan jika keluarga berkunjung pasien akan merasa disayangi, diperhatikan.

Hasil penelitian ini sejalan dengan teori yang dikemukakan oleh Dion dan Betan, (2013), yang mengatakan bahwa salah satu penatalaksanaan pada pasien risiko perilaku kekerasan adalah terapi keluarga seperti kunjungan keluarga. dimana kunjungan keluarga ini akan membangun rasa saling menyayangi, saling asuh, menerima anggota keluarga, mendukung antar anggota keluarga, memberi perhatian satu sama lain memberi cinta kasih dan memberi kehangatan.

\section{Kesembuhan pasien risiko perilaku kekerasan \\ Hasil penelitian yang dilakukan di} Rumah Sakit Jiwa Tampan Pekanbaru didapatkan kesembuhan yang kurang baik pada pasien risiko perilaku kekerasan terdapat 28 orang $(93,3 \%)$. Penelitian ini yang sesuai dengan teori Friedman, 
Juliana Putri ${ }^{1}$, Erna Marni ${ }^{2}$, Dian Roza Adila ${ }^{3}$,Hubungan Kunjungan Keluarga terhadap Kesembuhan Pasien Risiko Perilaku Kekerasan di Rumah Sakit Jiwa Tampan Pekanbaru

Bowden, \& Jones, (2013) yang menyatakan bahwa salah satu faktor yang dapat mempercepat proses pemulihan atau penyembuhan pasien risiko perilaku kekerasan adalah keterlibatan keluarga seperti memberi dukungan, memotivasi pasien untuk sembuh, tidak mengasingkan pasien dalam keluarga, serta memberi perhatian dan kasih sayang kepada pasien.

\section{Hubungan kunjungan keluarga terhadap kesembuhan pasien risiko perilaku kekerasan}

Hasil penelitian yang dilakukan di Rumah Sakit Jiwa Tampan Pekanbaru didapatkan bahwa pasien risiko perilaku kekerasan yang tidak mendapatkan kunjungan dari keluarganya (buruk) dan tingkat kesembuhannya kurang baik terdapat 28 orang $(93,3 \%)$. Berdasarkan hasil uji statistik Chi-Square didapatkan bahwa terdapat hubungan yang signifikan antara kunjungan keluarga terhadap kesembuhan pasien resiko perilaku kekerasan dengan $\mathrm{p}$ value $0,002<0,05$.

Penelitian ini sejalan dengan teori Harnilawati (2013), yang menyatakan bahwa dukungan keluarga dapat dilihat dari dukungan sosial keluarga, yaitu yang bermanfaat bagi individu, yang diperoleh dari orang lain misalnya anggota keluarga yang mengalami gangguan jiwa yang membutuhkan dukungan dari keluarganya. Dukungan yang dibutuhkan bisa dari motivasi, perhatian, kasih sayang dan juga bisa dari kunjungan rutin dimana kunjungan rutin ini akan mempercepat proses pemulihan atau penyembuhan pasien risiko perilaku kekerasan.

\section{SIMPULAN}

Berdasarkan penelitian yang telah dilakukan oleh peneliti di Rumah Sakit Jiwa Tampan Pekanbaru mengenai hubungan kunjungan keluarga terhadap kesembuhan pasien risiko perilaku kekerasan dapat diambil kesimpulan, rerata usia pasien risiko perilaku kekerasan di Rumah Sakit Jiwa Tampan Pekanbaru yaitu berusia 38,80 dan jenis kelamin pada pasien risiko perilaku kekerasan yaitu berjenis kelamin laki-laki sebanyak 22 orang $(73,3 \%)$. Rerata jumlah kunjungan yang berada di Rumah Sakit Jiwa Tampan Pekanbaru yaitu buruk dengan jumlah 28 orang $(93,3 \%)$ sehingga tingkat kesembuhan pada pasien risiko perilaku kekerasan dikatakan kurang baik yaitu dengan jumlah 28 orang $(93,3 \%)$.

Terdapat hubungan kunjungan keluarga terhadap kesembuhan pasien risiko perilaku kekerasan.

\section{SARAN}

Diharapkan bagi Rumah Sakit Jiwa Tampan Pekanbaru agar menetapkan ideal kunjungan keluarga dan membuat buku kunjungan disetiap ruangan rawat inap dan 
memaksimalkan fungsi dari buku kunjungan keluarga serta memotivasi keluarga supaya keluarga ingin mengunjungi anggota keluarganya yang berada di Rumah Sakit Jiwa. Diharapkan bagi peneliti lain penelitian ini dapat dijadikan data dasar dan informasi untuk melakukan penelitian lanjut tentang hubungan kunjungan keluarga terhadap intensitas kambuh pada pasien risiko perilaku kekerasan di Rumah Sakit Jia Tampan Pekanbaru.

\section{DAFTAR PUSTAKA}

Ardiyani, V, M., Kumboyono., \& Susmarini, D. (2017). Pengaruh dukungan keluarga terhadap peningkatan adaptasi pasien skizophrenia. Care: Jurnal Ilmiah Ilmu Kesehatan, 5(2), 184-193. Diperoleh dari https://scholar.google.co.id/

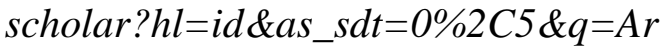
diyani\%2C.

Dion, Y., \& Betan, Y. (2013). Asuhan Keperawatan Keluarga Konsep dan Praktik. Yogyakarta: Nuha Medika.

Direja. A. H. S. (2011). Buku Ajar Asuhan Keperawatan Jiwa. Yogyakarta: Nuha Medika.

Donsu, J, D, T. (2016). Metodologi Penelitian Keperawatan. Yogyakarta: Pustakabarupress.

Efendi, F., \& Makhfudli. (2009). Keperawatan Kesehatan Komunitas Teori dan Praktik dalam Keperawatan. Jakarta: Salemba Medika.
Fajarwati, K., Ilyas, M., \& Anggriani, S. (2013). Hubungan Kunjungan Keluarga terhadap Kekambuhan Klien Gangguan Jiwa di Ruang Intermediate Rumah Sakit Khusus Daerah Provinsi Sulawesi Selatan. Jurnal Ilmiah Kesehatan Diagnosis, 3(1), 122-128. https://scholar.google.co.id/scholar?hl= id\&as_sdt=0\%2C5\&q=PENTINGNY $\mathrm{A}+\mathrm{KUNJUNGAN+KELUARGA \& btn}$ $\mathrm{G}=$

Friedman, M, M., Bowden,V, R., \& Jones, E, G. (2013). Buku Ajar Keperawatan Keluarga Riset, Teori \& Praktik. Jakarta: EGC.

Hamdani, R., Haryanto, T., \& Dewi, N. (2017). Hubungan dukungan keluarga dengan tingkat kepatuhan minum obat pada pasien skizofrenia di ruang rawat jalan rumah sakit jiwa mutiara sukma provinsi Nusa Tenggara Barat. 2 (3). 770-774. Diperoleh dari https:// scholar.google.co.id/scholar?hl=id.

Harnilawati. (2013). Konsep dan Proses Keperawatan Keluarga. Sulawesi Selatan: Pustaka As Salam.

Keliat, B., A., Akemat., Helena, N., \& Nurhaeni, H. (2014). Keperawatan Kesehatan Jiwa Komunitas :CHMN (Basic Course). Jakarta : EGC.

Keliat, B.A, dkk. 2011. Keperawatan Kesehatan Jiwa Komunitas: CMHN (Basic Course). Jakarta: EGC.

Kementrian Kesehatan RI. (2016). Peran Keluarga Dukung Kesehatan Jiwa Masyarakat. Dipublikasikan pada 06 Oktober 2016. Diakses pada tanggal 7 Februari 2018 dan diperoleh dari http://www.depkes.go.id/article/view/1 6100700005/peran-keluarga-dukungkesehatan-jiwa-masyarakat.html. 
Juliana Putri ${ }^{1}$, Erna Marni ${ }^{2}$, Dian Roza Adila ${ }^{3}$,Hubungan Kunjungan Keluarga terhadap Kesembuhan Pasien Risiko Perilaku Kekerasan di Rumah Sakit Jiwa Tampan Pekanbaru

Kirana, N., Nauli, F. A., \& Novayelinda, R. (2014). Efektifitas senam aerobic low Impact terhadap aggression self control pada pasien dengan resiko perilaku kekerasan. Jurnal Online Mahasiswa Program Studi Ilmu Keperawatan Universitas Riau, 1(2),1-9. Diperoleh dari https://scholar.google.co.id/scholar ?hl=id\&as_sdt=0\%2C5\&q.

Kusumawati, F., \& Hartono, Y. (2010). Buku Ajar Keperawatan Jiwa. Jakarta: Salemba Medika.

Melia, Y. (2016). Upaya keluarga dalam penyembuhan pasien penyakit jiwa; studi pada pasien penyakit jiwa di RSJ HB. sa'anin padang. Jurnal Ilmu Sosial Mamangan, 5(2), 102-112. Diperoleh dari https://scholar.google.co.id/scholar $? \mathrm{hl}=\mathrm{id} \&$ as_sdt $=0 \% 2 \mathrm{C} 5 \& \mathrm{q}=$ Melia $\% 2 \mathrm{C}$ +20 .

Muhith, A. (2015). Pendidikan Keperawatan Jiwa: Teori dan Aplikasi. Yogyakarta : CV Andi Offset.

Nasir, A., \& Muhith, A. ( 2011). Dasardasar Keperawatan jiwa, Pengantar dan Teori. Jakarta: Salemba Medika.

Ni'mah, S., \& Alvita, G. W. (2017). Dukungan keluarga terhadap kualitas hidup pasien gagal ginjal kronik pada usia dewasa yang menjalani hemodialisa di wilayah kerja puskesmas mejobo kudus tahun 2017. Prosiding hefa health events for all, 389-468.

Notoatmodjo, S. (2010). Metodologi Penelitian Kesehatan. Jakarta: Rineka Cipta.

Potter, P. A \& Perry, A. G (2010). Buku Ajar Fundamental Keperawatan. Edisi ketujuh, buku ketiga. Jakarta: EGC.
Prabowo, E. (2014). Konsep \& Aplikasi Asuhan Keperawatan Jiwa. Yogyakarta: Nuha Medika.

Rinawati, F., \& Alimansur, M. (2016). Analisa faktor-faktor penyebab gangguan jiwa menggunakan pendekatan model adaptasi stres stuart. Jurnal ilmu kesehatan, 5 (1). 34-38. Diperoleh dari https://scholar.google. co.id/scholar?hl=id.

Riset Kesehatan Dasar (Riskesdas). (2013). Badan Penelitian dan Pengembangan Kesehatan Kementerian RI tahun 2013. Diakses: 19 Oktober 2014, diperoleh dari https://www.google. com/search $? q=$ riskesdas $+2013 \& i e=u t$ $f-8 \& o e=u t f 8 \&$ client $=$ firefox $-b$.

Setiawan, A. \& Saryono. (2010). Metodologi Penelitian Kebidanan. Jakarta: Nuha Medika.

Sudiharto. (2012). Asuhan Keperawatan Keluarga dengan Pendekatan Keperawatan Transkultural. Jakarta: EGC.

Yosep, I., \& Titin, S. (2014). Buku Ajar Keperawatan Jiwa dan Advance Mental Health Nursing. Bandung: Refika Aditama 